\title{
FAKTOR RISIKO KEJADIAN SKIZOFRENIA DI RUMAH SAKIT JIWA GRHASIA DAERAH ISTIMEWA YOGYAKARTA (DIY)
}

\author{
Lina Handayani, Febriani, Aprilia Rahmadani, Azidanti Saufi \\ Fakultas Kesehatan Masyarakat, Universitas Ahmad Dahlan \\ Jalan Prof. Dr. Soepomo, S.H, Umbulharjo, Warungboto, Umbulharjo, Kota Yogyakarta, \\ Daerah Istimewa Yogyakarta 55164 \\ linafkm@gmail.com
}

\begin{abstract}
Schizophrenia is a mental disorder that is quite widespread in nature in Indonesia, which is about $99 \%$ of patients, the mental hospital in Indonesia are people with schizophrenia. The highest prevalence of psychosis is in DIY is 2.7 per 1000 population. Based on the data reports the top 10 disease hospitalization from January to June 2015 at the Mental Hospital Grhasia DIY disease schizophrenia is a disease with a high of 371 while other mental disorders as many as 54 people. This study aimed to determine risk factors of schizophrenia in patients hospitalized in the Psychiatric Hospital Grhasia DIY. This research was an analytic observational with cross sectional design. The sample was 79 people schizophrenia and non-schizophrenia. Data analysis was using Fisher's Exact Test. There were relationships between heredity $\mathrm{RP}=1.195$ (95\% CI 1.004 to 1.423$)$, psychosocial stressors of interpersonal relationship problems $\mathrm{RP}=1.257$ (CI95\% from 1.056 to 1.497), psychosocial stressors of family factors $\mathrm{RP}=1.366$ (CI95\% from 1.063 to 1.756 ) to the incidence of schizophrenia in-patients at the Mental Hospital Grhasia DIY. This research concluded that heredity, psychosocial stressors of interpersonal relationship problems and family factors are risk factors of the incidence of schizophrenia in the Mental Hospital DIY.
\end{abstract}

Keywords: heredity, interpersonal relationship problems, psychosocial stressors, schizophrenia

\begin{abstract}
Abstrak
Skizofrenia adalah gangguan mental yang cukup luas dialami di Indonesia, yaitu sekitar 99\% pasien RS Jiwa di Indonesia adalah penderita skizofrenia. Prevalensi psikosis tertinggi adalah di DIY yaitu 2,7 per 1000 penduduk. Berdasarkan laporan data 10 besar penyakit rawat inap bulan Januari-Juni 2015 di Rumah Sakit Jiwa Grhasia DIY penyakit skizofrenia merupakan penyakit tertinggi yaitu dengan 371 orang sedangkan gangguan mental lainnya sebanyak 54 orang. Penelitian ini bertujuan untuk mengetahui faktor risiko kejadian skizofrenia pada pasien rawat inap di Rumah Sakit Jiwa Grhasia DIY. Jenis Penelitian ini adalah analitik observasional dengan rancangan cross sectional. Sampel penelitian ini adalah 79 pasien skizofrenia dan tidak skizofrenia. Analisis data dengan
\end{abstract}


menggunakan uji Fisher 's Exact Test. Ada hubungan faktor keturunan RP=1,195 (CI 95\% 1,004-1,423), stresor psikososial dari masalah hubungan interpersonal $\mathrm{RP}=1,257$ (CI95\% 1,056-1,497), stresor psikososial dari faktor keluarga $\mathrm{RP}=1,366$ (CI95\% 1,063-1,756) dengan kejadian skizofrenia pada pasien rawat inap di Rumah Sakit Jiwa Grhasia DIY. Penelitian ini menyimpulkan bahwa faktor keturunan, stresor psikososial dari masalah hubungan interpersonal dan faktor keluarga merupakan factor risiko kejadian skizofrenia di Rumah Sakit Jiwa Grhasia DIY.

Kata kunci: faktor keturunan, masalah hubungan interpersonal, stresor psikososial, skizofrenia

\section{Pendahuluan}

Skizofrenia merupakan gangguan kejiwaan dan kondisi medis yang mempengaruhi fungsi otak manusia, mempengaruhi fungsi normal kognitif, mempengaruhi emosional dan tingkah laku (Depkes RI, 2015). Gangguan jiwa skizofrenia sifatnya adalah ganguan yang lebih kronis dan melemahkan dibandingkan dengan gangguan mental lain (Puspitasari, 2009).

Data America Psychiatric Association (APA) tahun 1995 menyebutkan bahwa $1 \%$ populasi penduduk dunia menderita skizofrena dan $75 \%$ penderita dari skizofrenia dapat terjadi pada usia 16-25 tahun (Depkes RI, 2015). Adapun data prevalensi penderita skizofrenia di Indonesia adalah $0,3-1 \%$ dan biasanya penyakit ini timbul di usia sekitar 18-45 tahun, dan ada juga yang baru berusia 11-12 tahun sudah menderita skizofrenia (Gunarsa, 2004).

Menurut Riset Kesehatan Dasar (Riskesdas) tahun 2007 bahwa prevalensi gangguan jiwa berat tertinggi terdapat di Provinsi DKI Jakarta yaitu sebesar 20,3 per 1000 penduduk. Adapun menurut Riset Kesehatan Dasar (Riskesdas) tahun 2013, bahwa prevalensi psikosis atau skizofrenia tertinggi adalah di DI Yogyakarta dan Aceh (masing-masing 2,7 per 1000 penduduk) (Riskesdas, 2007; Riskesdas, 2013).
Keberadaan penderita skizofrenia dalam masyarakat sering dianggap berbahaya. Seringkali penderita skizofrenia disembunyikan bahkan dikucilkan, tidak dibawa untuk berobat ke dokter karena adanya rasa malu. Bahkan di beberapa daerah di Indonesia penderita skizofrenia sebagian ada yang sampai dipasung (Hawari, 2014). Menurut Riset Kesehatan Dasar tahun 2013, mengatakan bahwa skizofrenia termasuk masalah kesehatan masyarakat yang menjadi perhatian karena dampak dari skizofrenia bukan hanya dirasakan oleh penderita dan keluarga tetapi juga masyakarakat serta pemerintah (Riskesdas, 2013).

Beban finansial yang ditimbulkan oleh skizofrenia, dapat berpengaruh pada individu yang menderita skizofrenia, keluarga maupun masyarakat, karena masih sering terdapatnya pandangan negatif (stigma). Akibatnya pasien dan keluarganya sering mendapat penolakan sosial dari masyarakat akibat ketidaktahuan masyarakat terhadap jenis gangguan jiwa (Hawari, 2001).

Membangun persepsi positif keluarga dan masyarakat dapat berperan serta dalam upaya pencegahan, terapi, rehabilitasi, dapat menerima kembali penderita skizofrenia ke keluarga dan masyarakat, tidak merasa "phobia" dan tidak bertindak diskriminatif terhadap penderita. Menurut Hawari (2014) 

(DIY)

mengatakan bahwa upaya pencegahan skizofrenia dapat dilakukan dengan pendekatan holistik yaitu pendekatan organobiologik, psikodinamik, psikoreligius dan psikososial (Hawari, 2014).

Berdasarkan laporan data 10 besar penyakit rawat inap di Rumah Sakit Jiwa Grhasia DIY bulan Januari sampai dengan Juni 2015, jenis-jenis skizofrenia di Rumah Sakit Jiwa Grhasia DIY yaitu undifferentiated schizophrenia sebanyak 156 orang, paranoid schizophrenia sebanyak 108 orang, schizoaffective disorder, manic type sebanyak 51 orang, residual schizophrenia sebanyak 25 orang, schizoaffective disorder, depressive type sebanyak 17 orang, hebephrenic schizophrenia sebanyak 7 orang dan acute schizophrenia-like psychotic disorder sebanyak 7 orang (SIMRS Grhasia, 2015).

Kejadian skizofrenia dipengaruhi oleh beberapa faktor. Faktor pertama adalah keturunan bahwa semakin dekat relasi seseorang dengan pasien skizofrenia, maka semakin besar risiko seseorang tersebut untuk mengalami penyakit skizofrenia (Arif, 2006). Faktor kedua stresor psikososial adalah setiap keadaan yang menimbulkan perubahan dalam hidup seseorang sehingga memaksa seseorang untuk melakukan penyesuaian diri (adaptasi) guna menanggulangi stresor (tekanan mental). Masalah stresor psikososial dapat digolongkan yaitu masalah perkawinan, masalah hubungan interpersonal, faktor keluarga dan faktor psikososial lain (penyakit fisik, korban kecelakaan atau bencana alam, masalah hukum, perkosaan dan lai-lain) (Hawari, 2014).

Faktor ketiga adalah tingkat pendidikan menurut hipotesis sosiogenik yang menunjukkan bahwa tingkat pendidikan yang rendah dapat berakibat pada stres yang dapat menjadi faktor terjadinya skizofrenia (Sue, dkk, 2014). Faktor keempat adalah status pekerjaan, masalah pekerjaan dapat merupakan sumber stres pada diri seseorang yang bila tidak diatasi yang bersangkutan dapat jatuh sakit dan dapat memicu terjadinya skizofrenia (Hawari, 2014).

Tujuan penelitian ini untuk mengetahui faktor risiko kejadian skizofrenia pada pasien rawat inap di Rumah Sakit Jiwa Grhasia DIY.

\section{Metode Penelitian}

Penelitian ini merupakan penelitian epidemiologi analitik observasional dengan menggunakan rancangan penelitian studi cross sectional. Populasi dalam penelitian ini adalah seluruh pasien gangguan jiwa rawat inap yang telah tercatat di laporan data 10 besar penyakit rawat inap di Rumah Sakit Jiwa Grhasia DIY pada bulan Januari-Juni 2015 yang berjumlah 425 orang. Sampel dalam penelitian ini adalah 79 orang dengan teknik simple random sampling.

Instrumen yang digunakan dalam penelitian ini adalah lembar check list untuk mengetahui faktor risiko terjadinya skizofrenia pada pasien rawat inap di Rumah Sakit Jiwa Grhasia DIY. Analisis data pada penelitian ini adalah univariat dan bivariat. Analisis univariat menggunakan tabel dan narasi, sedangkan analisis bivariat menggunakan uji Fisher's Exact Test.

\section{Hasil dan Pembahasan}

Hasil analisis univariat didapatkan dengan menghitung distribusi frekuensi sebaran jenis kelamin, umur, dan status perkawinan yang disajikan dalam Tabel 1 . 
Tabel 1. Distribusi Frekuensi Responden Rawat Inap Menurut Jenis Kelamin, Umur dan Status Perkawinan di Rumah Sakit Jiwa Grhasia DIY

\begin{tabular}{llc}
\hline \multirow{2}{*}{ Variabel } & \multicolumn{2}{c}{ Frekuensi } \\
\cline { 2 - 3 } Jenis Kelamin & $\mathrm{n}$ & $\%$ \\
a. Laki-laki & 42 & 53,2 \\
b. Perempuan & 37 & 46,8 \\
Umur & & \\
a. 15-24 & 10 & 12,7 \\
b. 25-44 & 44 & 55,7 \\
c. 45-54 & 16 & 20,3 \\
d. $\geq 55$ & 9 & 11,4 \\
Status Perkawinan & & \\
a. Menikah & 32 & 40,5 \\
b. Tidak Menikah & 47 & 59,5 \\
\hline Total & $\mathbf{7 9}$ & $\mathbf{1 0 0}$ \\
\hline
\end{tabular}

Tabel 1 menunjukkan bahwa responden jumlah jenis kelamin lakilaki cenderung lebih banyak daripada perempuan dengan persentase 53,2\% lakilaki dan $46,8 \%$ perempuan. Umur responden terbanyak berkisar 25-44 tahun yaitu sebesar 55,7\%. Adapun status perkawinan responden menunjukkan hasil bahwa banyak responden yang tidak menikah sebesar $59,5 \%$ dibandingkan dengan responden yang menikah sebesar $40,5 \%$. Adapun data distribusi frekuensi menurut variabel penelitian dapat dilihat pada Tabel 2 .

Tabel 2. Distribusi Frekuensi Responden Rawat Inap Menurut Faktor Risiko Kejadian Skizofrenia di Rumah Sakit Jiwa Grhasia DIY

\begin{tabular}{|c|c|c|c|c|c|c|}
\hline \multirow{3}{*}{ Variabel } & \multicolumn{4}{|c|}{$\begin{array}{c}\text { Kejadian } \\
\text { Skizofrenia }\end{array}$} & \multirow{2}{*}{\multicolumn{2}{|c|}{ Total }} \\
\hline & \multicolumn{2}{|c|}{$\mathrm{Ya}$} & \multicolumn{2}{|c|}{ Tidak } & & \\
\hline & $\mathrm{N}$ & $\%$ & $\mathrm{~N}$ & $\%$ & $\mathrm{~N}$ & $\%$ \\
\hline \multicolumn{7}{|l|}{ Keturunan } \\
\hline a. $\mathrm{Ya}$ & 38 & 55 & 2 & 20 & 40 & 51 \\
\hline b. Tidak & 31 & 45 & 8 & 80 & 39 & 49 \\
\hline \multicolumn{7}{|l|}{ Stresor Psikososial } \\
\hline 1) Masalah Perkawinan & & & & & & \\
\hline a. Ya & 25 & 36 & 3 & 30 & 28 & 35 \\
\hline b. Tidak & 44 & 64 & 7 & 70 & 51 & 65 \\
\hline
\end{tabular}

2) Masalah Hubungan

Interpersonal $\begin{array}{lllllll}\text { a. Ya } & 38 & 55 & 1 & 10 & 39 & 49\end{array}$ $\begin{array}{lllllll}\text { b. Tidak } & 31 & 45 & 9 & 90 & 40 & 51\end{array}$

3) Faktor Keluarga $\begin{array}{lllllll}\text { a. Ya } & 50 & 72 & 2 & 20 & 52 & 66\end{array}$ $\begin{array}{lllllll}\text { b. Tidak } & 19 & 28 & 8 & 80 & 27 & 34\end{array}$

4) Faktor Psikososial Lain

a. Ya

b. Tidak

$\begin{array}{llllll}48 & 70 & 6 & 60 & 54 & 68\end{array}$

Tingkat Pendidikan

a. Rendah

b. Tinggi

$\begin{array}{llllll}21 & 30 & 4 & 40 & 25 & 32\end{array}$

Status Pekerjaan

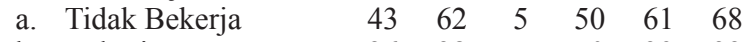

\begin{tabular}{lcccccc} 
b. Bekerja & 26 & 38 & 5 & 50 & 39 & 32 \\
\hline Total & 69 & 100 & 10 & 100 & 79 & 100
\end{tabular}

Tabel 2 menunjukkan bahwa total subyek penelitian kelompok skizofrenia sebanyak 69 orang dan tidak skizofrenia sebanyak 10 orang. Subyek penelitian kelompok skizofrenia dan tidak skizofrenia yang memiliki riwayat keturunan lebih banyak dibandingkan dengan yang tidak memiliki riwayat keturunan yaitu sebesar $51 \%$.

Stresor psikososial dari masalah perkawinan menunjukkan bahwa subyek penelitian kelompok skizofrenia dan tidak skizofrenia banyak yang tidak memiliki masalah perkawinan dibandingkan dengan yang menderita skizofrenia yang memiliki masalah perkawinan yaitu sebesar $64 \%$. Subyek penelitian kelompok skizofrenia dan tidak skizofrenia yang tidak memiliki stresor psikososial dari masalah hubungan interpersonal lebih banyak dibandingkan dengan yang memiliki hubungan interpersonal yaitu sebesar 49\%. Subyek penelitian kelompok skizofrenia dan tidak skizofrenia menunjukkan bahwa yang memiliki stresor psikososial dari faktor keluarga lebih banyak dibandingkan dengan yang tidak yaitu sebesar 66\%. Subyek penelitian kelompok skizofrenia dan tidak skizofrenia menunjukkan bahwa yang 

(DIY)

memiliki stresor psikososial dari faktor psikososial lain memiliki persentase lebih besar dibandingkan dengan yang tidak yaitu sebesar $68 \%$.

Subyek penelitian kelompok skizofrenia dan tidak skizofrenia menunjukkan bahwa tingkat pendidikan yang paling banyak dimiliki adalah tingkat pendidikan rendah yaitu sebesar $61 \%$. Adapun status pekerjaan responden yang terbanyak adalah berstatus tidak bekerja yaitu sebesar $68 \%$ dibandingkan dengan responden yang bekerja.

Analisis bivariat merupakan analisis untuk mengetahui hubungan variabel bebas dan terikat. Uji statistik yang digunakan untuk mengetahui hubungan dua variabel ini adalah uji Fisher's Exact Test dikarenakan syarat uji Chi-Square tidak terpenuhi yaitu terdapat 1 sel yang nilai expected count-nya kurang dari lima. Hasil analisis bivariat dapat dilihat pada Tabel 3.

Tabel 3. Hasil Analisis Bivariat Hubungan Faktor Risiko Kejadian Skizofrenia pada Pasien Rawat Inap di Rumah Sakit Jiwa Grhasia DIY

\begin{tabular}{|c|c|c|c|c|c|c|c|c|c|}
\hline \multirow{3}{*}{ Variabel } & \multicolumn{4}{|c|}{ Kejadian Skizofrenia } & \multirow{2}{*}{\multicolumn{2}{|c|}{ Total }} & \multirow{3}{*}{$\mathrm{RP}$} & \multirow{3}{*}{ CI 95\% } & \multirow{3}{*}{$p$ Value } \\
\hline & \multicolumn{2}{|c|}{ Ya } & \multicolumn{2}{|c|}{ Tidak } & & & & & \\
\hline & $\mathrm{N}$ & $\%$ & $\mathrm{n}$ & $\%$ & $\mathrm{n}$ & $\%$ & & & \\
\hline $\begin{array}{l}\text { Keturunan } \\
\text { a. Ya } \\
\text { b. Tidak }\end{array}$ & $\begin{array}{l}38 \\
31\end{array}$ & $\begin{array}{l}55 \\
45\end{array}$ & $\begin{array}{l}2 \\
8\end{array}$ & $\begin{array}{l}20 \\
80\end{array}$ & $\begin{array}{l}40 \\
39\end{array}$ & $\begin{array}{l}51 \\
49\end{array}$ & 1,195 & $\begin{array}{c}1,004- \\
1,423\end{array}$ & 0,048 \\
\hline Stresor Psikososial & & & & & & & & & \\
\hline $\begin{array}{l}\text { 1) Masalah Perkawinan } \\
\text { a. Ya } \\
\text { b. Tidak }\end{array}$ & $\begin{array}{l}25 \\
44\end{array}$ & $\begin{array}{l}36 \\
64\end{array}$ & $\begin{array}{l}3 \\
7\end{array}$ & $\begin{array}{l}30 \\
70\end{array}$ & $\begin{array}{l}28 \\
51\end{array}$ & $\begin{array}{l}35 \\
65\end{array}$ & 1,035 & $\begin{array}{c}0,874- \\
1,225\end{array}$ & 1,000 \\
\hline $\begin{array}{l}\text { 2) Masalah Hubungan Interpersonal } \\
\text { a. Ya } \\
\text { b. Tidak }\end{array}$ & $\begin{array}{l}38 \\
31\end{array}$ & $\begin{array}{l}55 \\
45\end{array}$ & $\begin{array}{l}1 \\
9\end{array}$ & $\begin{array}{l}10 \\
90\end{array}$ & $\begin{array}{l}39 \\
40\end{array}$ & $\begin{array}{l}49 \\
51\end{array}$ & 1,257 & $\begin{array}{c}1,056- \\
1,497\end{array}$ & 0,014 \\
\hline $\begin{array}{l}\text { 3) Faktor Keluarga } \\
\text { a. Ya } \\
\text { b. Tidak }\end{array}$ & $\begin{array}{l}50 \\
19\end{array}$ & $\begin{array}{l}72 \\
28\end{array}$ & $\begin{array}{l}2 \\
8\end{array}$ & $\begin{array}{l}20 \\
80\end{array}$ & $\begin{array}{l}52 \\
27\end{array}$ & $\begin{array}{l}66 \\
34\end{array}$ & 1,366 & $\begin{array}{c}1,063- \\
1,756\end{array}$ & 0,002 \\
\hline $\begin{array}{l}\text { 4) Faktor Psikososial Lain } \\
\text { a. Ya } \\
\text { b. Tidak }\end{array}$ & $\begin{array}{l}48 \\
21\end{array}$ & $\begin{array}{l}70 \\
30\end{array}$ & $\begin{array}{l}6 \\
4\end{array}$ & $\begin{array}{l}60 \\
40\end{array}$ & $\begin{array}{l}54 \\
25\end{array}$ & $\begin{array}{l}68 \\
32\end{array}$ & 1,058 & $\begin{array}{c}0,870- \\
1,286\end{array}$ & 0,717 \\
\hline $\begin{array}{l}\text { Tingkat Pendidikan } \\
\text { a. Rendah } \\
\text { b. Tinggi }\end{array}$ & $\begin{array}{l}42 \\
27\end{array}$ & $\begin{array}{l}61 \\
39\end{array}$ & $\begin{array}{l}6 \\
4\end{array}$ & $\begin{array}{l}60 \\
40\end{array}$ & $\begin{array}{l}48 \\
31\end{array}$ & $\begin{array}{l}61 \\
39\end{array}$ & 1,005 & $\begin{array}{c}0,845- \\
1,194\end{array}$ & 1,000 \\
\hline $\begin{array}{l}\text { Status Pekerjaan } \\
\text { a. Tidak Bekerja } \\
\text { b. Bekerja }\end{array}$ & $\begin{array}{l}43 \\
26 \\
\end{array}$ & $\begin{array}{l}62 \\
38 \\
\end{array}$ & $\begin{array}{l}5 \\
5 \\
\end{array}$ & $\begin{array}{l}50 \\
50 \\
\end{array}$ & $\begin{array}{l}61 \\
39 \\
\end{array}$ & $\begin{array}{l}68 \\
32 \\
\end{array}$ & 1,068 & $\begin{array}{c}0,890- \\
1,281\end{array}$ & 0,502 \\
\hline Total & 69 & 100 & 10 & 100 & 79 & 100 & & & \\
\hline
\end{tabular}

Tabel 3 menunjukkan bahwa hasil statistik uji Fisher's Exact Test antara variabel keturunan, stresor psikososial dari masalah hubungan interpersonal dan faktor keluarga memiliki hubungan dengan kejadian skizofrenia pada pasien rawat inap di Rumah Sakit Jiwa Grhasia DIY dengan $\mathrm{P}$ value $<0,05$.
Hasil penelitian tentang faktor risiko kejadian skizofrenia di Rumah Sakit Jiwa Grhasia DIY, dari variabel keturunan, stresor psikososial (masalah perkawinan, masalah hubungan interpersonal, faktor keluarga dan faktor psikososial lain) sebagai berikut: 
1. Faktor Keturunan

Faktor keturunan menunjukkan nilai $\mathrm{P}$ value 0,048 , artinya ada hubungan antara faktor keturunan dengan kejadian skizofrenia pada pasien rawat inap di Rumah Sakit Jiwa Grhasia DIY. Nilai RP 1,195 dengan CI 95\% 1,004-1,423, artinya orang yang memiliki faktor keturunan berisiko 1,195 kali lebih besar terkena skizofrenia dibandingkan dengan orang yang tidak memiliki faktor keturunan. Hal ini berarti variabel keturunan bermakna secara statistik dan bermakna secara biologi (Sastroasmoro, 2011).

Menurut Arif (2006), berbagai penelitian menunjukkan bahwa gen yang diwarisi seseorang, sangat kuat mempengaruhi resiko seseorang mengalami skizofrenia. Studi pada keluarga telah menunjukkan bahwa semakin dekat relasi seseorang dengan pasien Skizofrenia, makin besar risikonya untuk mengalami penyakit tersebut. Berdasarkan teori Blum (1974) dalam Notoatmojo (2007) bahwa derajat kesehatan masyarakat dipengaruhi oleh empat faktor yaitu genetik, pelayanan kesehatan, perilaku dan lingkunga yang saling mempengaruhi satu sama lain. Faktor keturunan memiliki risiko lebih besar terkena skizofrenia apabila dipengaruhi oleh stresor psikososial baik berasal dari diri sendiri maupun lingkungan.

Hal ini mengakibatkan seseorang yang mempunyai kerentanan genetik skizofrenia akan sangat sulit menangani stresor psikososial di dalam kehidupannya dibandingkan dengan orang yang tidak memiliki kerentanan genetik. Selain menyebabkan produktifitas seseorang yang skizofrenia menjadi menurun tetapi juga berdampak pada derajat kesehatannya yang ikut menurun (Kumpulan Artikel Kesehatan, 2016). Adapun pentingnya melakukan konsultasi ke pelayanan kesehatan jiwa apabila salah satu keluarga memiliki riwayat skizofrenia, sehingga stresor psikososial yang mempengaruhi terjadinya skizofrenia akibat faktor keturuanan dapat diminimalisir.

Hasil penelitian yang dilakukan Akal et al (2010) menunjukkan hasil bahwa responden pada kelompok pasien (patient group) cenderung lahir dari orangtua yang lebih tua daripada responden pada kelompok kontrol. Analisis menunjukkan bahwa seorang ayah yang berusia lebih tua merupakan faktor risiko untuk skizofrenia pada umumnya. Studi di Swedia dan Denmark menunjukkan bahwa seorang ayah yang beruisa lebih tua merupakan faktor dalam peningkatan risiko yang signifikan terhadap psikosis, sedangkan tidak ada hubungan yang ditemukan di Australia (El-Saadi et al, 2004). Hal ini menegaskan bahwa usia antara 35-40 tahun meningkatkan risiko skizofrenia (Brown, 2002; Mc Grath dan Susser, 2009; Byrne el al, 2003).

Riwayat konsumsi obat selama hamil memiliki hubungan dengan peningkatan kejadian skizofrenia (Brown, 2002; Byrne el al, 2003). Penelitian di Cina dan Belanda menunjukkan bahwa kekurangan gizi meningkatkan insiden skizofrenia (Tandon el al, 2008; Tien dan Eaton, 1992). Wahlbeck el al (2001) melakukan penelitian di Firlandia menemukan bahwaintrauterine dan defisiensi gizi pada anak dikaitkan dengan risiko skizofrenia seumur hidup. Kekurangan kalori protein, kekurangan zat gizi mikro (retinoid dan assal lemak), folat dan vitamin D selama kehamilan dapat meningkatkan risiko skizofrenia (Mc Grath, 1999; Mc Grath dan Welham, 2001).

Penelitian di Indonesia yang dilakukan Amirudin (2010), yang menyatakan bahwa riwayat keturunan (faktor keturunan) memiliki hubungan dengan kejadian gangguan jiwa skizofrenia dengan nilai 

(DIY)

$\mathrm{P}$ value $0,00(\mathrm{P}$ value $<0,05)$. Penelitian Setiyowati (2012) sejalan dengan penelitian ini yang menyatakan bahwa ada hubungan antara riwayat keluarga dengan kejadian skizofrenia $(\mathrm{P}$ value $=0,000)$.

2. Stresor Psikososial dari Masalah Perkawinan

Variabel stresor psikososial dari masalah perkawinan memperoleh nilai $\mathrm{P}$ value 1,000 yang berarti tidak ada hubungan masalah perkawinan dengan kejadian skizofrenia pada pasien rawat inap di Rumah Sakit Jiwa Grhasia DIY. Nilai RP 1,035 dengan CI 95\% 0,874-1,225, artinya stresor psikososial dari masalah perkawinan bukan merupakan faktor risiko kejadian skizofrenia pada pasien rawat inap di Rumah Sakit Jiwa Grhasia DIY (Sastroasmoro, 2011).

Hasil penelitian ini sesuai dengan penelitian Setiyowati (2012) yang menyatakan bahwa tidak ada hubungan masalah ketidakharmonisan perkawinan pribadi dengan kejadian skizofrenia. Penelitian lain yang dilakukan Erlina dkk (2010) yaitu tidak terdapat perbedaan yang bermakna antara status perkawinan dengan timbulnya skizofrenia dan no skizofrenia $(\mathrm{OR}=1,598: 95 \% \mathrm{CI}: 0,594-4,61, \mathrm{p}>0,390)$. Mallett et al (2002) juga menyatakan tidak ada hubungan antara status perkawinan terhadap timbulnya skizofrenia, tetapi berbeda dengan penelitian yang dilakukan Fakhari et al (2005) yang menyatakan ada perbedaan terhadap kejadian gangguan jiwa skizofrenia $(\mathrm{p}<0,001)$.

Soewadi (2004) menerangkan bahwa status marital perlu untuk pertukaran ego ideal dan identifikasi perilaku antara suami dan istri menuju tercapainya kedamaian. Maramis (1994) menambahkan bahwa perhatian dan kasih sayang adalah fundamental bagi percapaian suatu hidup yang berarti dan memuaskan (Erlina dkk,
2010).

Stresor psikososial dari masalah perkawinan bukan merupakan faktor risiko kejadian skizofrenia. Blum (1974) dalam Notoatmojo (2007) menerangkan bahwa ada faktor lain yang mempengaruhi terjadinya skizofrenia. Oleh karena faktor-faktor lingkungan yang mempengaruhi kesehatan mental seseorang akan terus berinteraksi, sehingga suatu stres tidak akan menimbulkan gangguan pada seseorang selama stres itu dapat diatasi dengan baik.

3. Stresor Psikososial dari Masalah Hubungan Interpersonal

Stresor psikososial dari masalah hubungan interpersonal menurut Hawari (2014), dapat berupa hubungan dengan kawan dekat yang mengalami konflik, atau konflik dengan kekasih, konflik dengan rekan sekerja, konflik dengan atasan dan bawahan dan lain sebagainya. Konflik antar pribadi ini dapat merupakan sumber stres bagi seseorang yang bila tidak dapat diperbaiki (silahturahim) yang bersangkutan dapat jatuh sakit.

Hasil uji statistik Fisher's Exact Test diketahui nilai $\mathrm{P}$ value 0,014 , artinya ada hubungan antara stresor psikososial dari masalah hubungan interpersonal dengan kejadian skizofrenia. Nilai RP 1,257 dengan CI 95\% 1,056-1,497 (tidak mencakup angka 1), artinya orang yang memiliki stresor psikososial dari masalah hubungan interpersonal berisiko 1,257 kali lebih besar terkena skizofrenia dibandingkan dengan orang yang tidak memiliki stresor psikososial dari masalah hubungan interpersonal (Sastroasmoro, 2011).

Berdasarkan hasil observasi penelitian ini di Rumah Sakit Jiwa Grhasia DIY menunjukkan bahwa pasien skizofrenia yang memiliki stresor psikososial dari masalah hubungan interpersonal lebih banyak yaitu 
sebanyak 38 orang dibandingkan dengan yang tidak. Adapun ini disebabkan oleh masih banyak pasien yang tidak mampu untuk mengelolah stres dengan baik akibat konflik yang tidak dapat diselesaikan sehingga akan mengakibatkan depresi dan stres.

Teori Blum dalam Notoatmodjo (2007) menyebutkan bahwa keempat faktor yang mempengaruhi derajat kesehatan masyarakat adalah faktor lingkungan, perilaku, keturunan dan pelayanan kesehatan . Adanya pasien yang memiliki hubungan interpersonal yang buruk sangat mempengaruhi lingkungan sosialnya dengan sesama teman, rekan kerja, tetangga maupun masyarakat. Hal ini tentunya dapat menjadi tekanan berat bagi orang tersebut yang bila tidak diperbaiki maka akan mempengaruhi kesehatan mental orang tersebut, sehingga menjadi rentan untuk terkena skizofrenia.

Pentingnya kegiatan psikoreligius berguna untuk mengurangi stres pasien akibat konflik antar pribadi ini, sehingga dapat mengurangi rasa depresi, permusuhan, penyakit hati dan sebagainya. Ritual keagamaan seperti sholat, dzikir, membaca Al-Qur'an untuk umat muslim dan bagi umat non-muslim dapat membaca kajian Kitab sangat bermanfaat untuk mengurangi stres tersebut (Hawari, 2014).

Hal ini dapat di lihat dari redefinisi sehat menurut WHO (1984) dalam Hawari (2014) yang menyebutkan bahwa yang dimaksud sehat tidak hanya dari segi jasmani, jiwa dan sosial saja tetapi juga dari segi spiritual (agama). Hasil penelitian ini sejalan dengan penelitian Setiyowati (2012) yang menyatakan bahwa ada hubungan antara masalah hubungan interpersonal dengan kejadian skizofrenia $(\mathrm{P}$ value $=$ 0,000 dan $\mathrm{OR}=8,8$ ).
4. Stresor Psikososial dari Faktor Keluarga Stresor psikososial dari faktor keluarga didapatkan nilai P value 0,002, artinya ada hubungan antara stresor psikososial dari faktor keluarga dengan kejadian skizofrenia pada pasien rawat inap di Rumah Sakit Jiwa Grhasia DIY. Nilai RP 1,366 dengan CI 95\% 1,063-1,756, artinya orang yang dengan faktor keluarga berisiko 1,366 kali lebih besar terkena skizofrenia dibandingkan dengan orang yang tidak dengan faktor keluarga (Sastroasmoro, 2011). Penelitian ini sejalan dengan Townsead, dkk (2007) yang menyatakan bahwa ada hubungan yang signifikan antara problem keluarga yang tidak terpecahkan dengan gejala-gejala depresi yang persisten.

Konflik keluarga sangat mempengaruhi perkembangan psikopatologis anak. Konflik dalam keluarga juga akan mempengaruhi sikap atau didikan orangtua terhadap anak, dan sikap orangtua sangat berpengaruh terhadap pola asuh kepada anak. Konflik keluarga tidaklah langsung menimbulkan gangguan jiwa skizofrenia tetapi konflik keluarga yang berlarutlarut dapat menggangu perkembangan mentak seseorang yang jika pribadi itu rentan dapat menimbulkan gangguan jiwa skizofrenia (Townsead et al, 2007). Safarino (1990) dalam Erlina (2010) menyatakan stresor psikososial faktor keluarga (konflik keluarga) dapat mengakibatkan kehilangan rasa aman, kehilangan rasa cinta, perasaan istimewa dan akan membekas sampai dewasa awal.

Menurut Hawari (2014), faktor keluarga merupakan faktor stres yang dialami oleh anak dan remaja yang disebabkan oleh karena kondisi keluarga yang tidak baik (sikap orangtua). Pola pengasuhan orangtua mempengaruhi perkembangan perilaku sosial anak. Terjadinya skizofrenia kemungkinan disebabkan pada masa 

(DIY)

kanak-kanaknya mendapatkan perlakukan kekerasan, sehingga menimbulkan trauma yang mendalam pada diri anak $(\operatorname{Read}$ et al, 2005).

Menurut Blum (1974), bahwa faktor perilaku dan sikap dapat memperngaruhi derajat kesehatan seseorang, seperti sikap orang tua yang yang dingin atau acuh tak acuh, orang tua yang jarang di rumah dan tidak ada waktu untuk bersama anakanaknya, orangtua dan lain sebagainya dapat mengganggu kesehatan mental seorang anak. Hal ini dapat menyebabkan stresor psikososialnya semakin berat dan berisiko terkena skizofrenia (Notoatmojo, 2007).

Dalam keadaan krisis timbul bermacam-macam perasaan yang tidak enak, seperti cemas, takut, rasa salah atau malu, tergantung pada keadaan. Pengaruh keluarga sangat menolong individu dalam mengatasi krisis sesuai dengan adat istiadat, kebudayaan atau pengalaman keluarga itu. Keluarga harus menolong individu agar secara aktif menemukan cara nenyelesaikan masalahnya dan bukan untuk menghidar tantangan atau memakai mekanissme pembelaan yang sekedar untuk menghilangkan ketegangan. Pada waktu krisis individu itu lebih membutuhkan dan lebih tergantung pada hubungan antar manusia(Read et al, 2005).

\section{Stresor Psikososial dari Faktor Psikososial Lain}

Stresor psikososial faktor psikososial lain didapatkan nilai $\mathrm{P}$ value 0,717 , artinya tidak ada hubungan antara faktor psikososial lain dengan kejadian skizofrenia pada pasien rawat inap di Rumah Sakit Jiwa Grhasia DIY. Nilai RP 1,058 dengan CI 95\% 0,8701,286 , artinya stresor psikososial dari faktor psikososial lain bukan merupakan faktor risiko kejadian skizofrenia pada pasien rawat inap di Rumah Sakit Jiwa Grhasia
DIY (Sastroasmoro, 2011).

Faktor psikososial lain yang menimbulkan trauma fisik maupun mental seperti kekerasan fisik, penganiayaan dan perampokan, perkosaan, sakit berat/cidera, menjadi korban bencana alam dapat menjadi stresor psikososial yang dapat menimbulkan depresi. Adapun stresor psikososial yang berhubungan dengan kejadian skizofrenia adalah masalah hubungan interpersonal dan faktor keluarga.

Berdasarkan hasil observasi penelitian ini di Rumah Sakit Jiwa Grhasia DIY menunjukkan bahwa pasien skizofrenia yang memiliki stresor psikososial faktor psikososial lain lebih banyak yaitu sebanyak 48 orang dibandingkan dengan yang tidak. Walaupun secara statistik tidak berhubungan, hal ini dapat disebabkan oleh masih banyak pasien yang tidak mampu untuk mengelolah stres dengan baik sehingga akan mengakibatkan sakit. Kegiatan psikoreligius berguna untuk mengurangi stres pasien akibat trauma, rasa bersalah (dosa), depresi dan sebagainya, sehingga dapat membuat hati tenang. Ritual keagamaan seperti sholat, dzikir dan doa untuk meminta pertolongan dan pengampunan, membaca Al-Qur'an untuk umat muslim dan bagi umat nonmuslim dapat membaca kajian Kitab sangat bermanfaat untuk mengurangi stres tersebut.

Peran agama menjadi semakin penting di bidang kesehatan dan dunia kedokteran. Oleh karena setiap orang membutuhkan rasa aman, tenang, tentram, terlindung, bebas dari rasa cemas, ketakutan, depresi, stress dan sebagainya. bagi mereka yang beragama kebutuhan kerohanian dapat diperoleh lewat agama. Hal ini dapat di lihat dari redefinisi sehat menurut WHO (1984) dalam Hawari (2014) yang menyebutkan bahwa yang dimaksud sehat tidak hanya dari segi jasmani, jiwa dan sosial saja tetapi juga dari segi spiritual (agama). 
Adapun teori Blum (1974) dalam Notoatmojo (2007), bahwa faktor lain yang mempengaruhi derajat kesehatan seseorang salah satunya adalah kesehatan mental, apabila kesehatan mental dipengaruhi oleh empat faktor utama yaitu faktor keturunan, pelayanan kesehatan, perilaku dan lingkungan, maka hal tersebut dapat berisiko menurunnya derajat kesehatan seseorang. Faktor psikososial lain merupakan stresor psikososial yang menyebabkan seseorang mengalami gangguan kejiwaan. Tentunya faktor ini tidak berdiri sendiri untuk menyebabkan seseorang mengalami skizofrenia karena terjadinya skizofrenia itu disebabkan oleh multifaktor. Apabila seseorang dapat menghadapi stresnya dengan baik maka dapat mengurangi terjadinya skizofrenia (Hawari, 2014; Notoatmojo, 2007). Hasil penelitian ini sejalan dengan penelitian Setiyowati (2012) menyatakan bahwa tidak ada hubungan faktor psikososial lain dengan kejadian skizofrenia.

\section{Tingkat Pendidikan}

Variabel tingkat pendidikan didapatkan nilai $\mathrm{P}$ value 1,000, artinya tidak ada hubungan antara tingkat pendidikan dengan kejadian skizofrenia pada pasien rawat inap di Rumah Sakit Jiwa Grhasia DIY. Nilai RP 1,005 dengan CI 95\% 0,845-1,194, artinya artinya bahwa tingkat pendidikan rendah bukan merupakan faktor risiko terjadinya skizofrenia (Sastroasmoro, 2011). Hasil penelitian ini bertentangan dengan penelitian yang dilakukan Fakhari et al (2005) dengan hasil ada hubungan yang bermakna anatara tidka ounya pendidikan atau tidak tamat SD dengan timbulnya gangguan jiwa $(p<0,001)$.

Berdasarkan hasil observasi penelitian ini di Rumah Sakit Jiwa Grhasia DIY menunjukkan bahwa pasien yang menderita skizofrenia banyak yang pendidikannya rendah yaitu sebanyak 42 orang. Hal ini dapat disebabkan oleh banyaknya pasien yang terpaksa tidak melanjutkan sekolah karena menderita skizofrenia. Adapun tingkat pendidikan yang rendah akan mempengaruhi pengetahuan pasien tentang skizofrenia menjadi rendah pula sehinggan akan menjadi hambatan dalam berinteraksi sosial maupun dalam mendapatkan informasi tentang skizofrenia. Akibatnya keluarga maupun masyarakat masih memiliki pandangan yang buruk terhadap orang yang menderita skizofrenia, sehingga banyak penderita skizofrenia telat untuk dibawa ke pelayanan kesehatan jiwa. Kejadian ini mengakibatkan banyak pasien skizofrenia menjadi sukar untuk disembuhkan.

Adapun pentingnya penyebaran informasi tentang skizofrenia, cara pencegahan, penanggulangan, maupun cara pengobatan skizofrenia dapat dilakukan dengan promosi kesehatan mental (penyuluhan dan sosialisasi kesehatan mental maupun mengadakan diskusi (Focus Group Discussion)) maupun psiko-edukatif dan lain sebagainya kepada penderita, keluarga dan masyarakat dengan cara yang mudah untuk dipahami oleh semua orang baik yang berpendidikan rendah maupun tinggi. Hal ini akan bermanfaat untuk menambah pengetahuan, mengurangi kekambuhan maupun stigma negatif masyarakat kepada penderita skizofrenia, mengingat penderita skizofrenia yang berpendidikan rendah sebesar $61 \%$.

Peran penting kegiatan promosi kesehatan jiwa selain untuk menghilangkan stigma juga memberikan pengetahuan kepada keluarga dan masyarakat tentang ikhwal gangguan jiwa skizofrenia itu sendiri. Hal ini diharapkan pihak keluarga dan masyarakat dapat berperan serta dalam 

(DIY)

upaya pencegahan, terapi, rehabilitasi, dapat menerima kembali penderita ke keluarga dan masyarakat, tidak merasa "phobia" dan tidak bertindak dikriminatif (Hawari, 2014)

Berdasarkan teori Gordon (1950) dalam Rajab (2008), bahwa suatu penyakit tidak tergantung pada suatu sebab yang berdiri sendiri melainkan akibat dari proses sebab-akibat.Tentunya ini akan berpengaruh pada lingkungan sosial mereka yang dapat menyebabkan stres apabila tidak dapat atasi dengan baik. Hal ini dikarenakan faktor-faktor yang mempengaruhi terjadinya skizofrenia akan terus berputar mempengaruhi kesehatan mental seseorang apabila orang tersebut tidak berusaha untuk melakukan coping terhadap faktor-faktor yang menyebabkan timbulnya stres sebagai risiko terjadinya skizofrenia (Rajab, 2008). Penelitian ini sejalan dengan penelitian Junaidi (2008) yang menyatakan bahwa tidak ada hubungan tingkat pendidikan terhadap timbulnya gangguan jiwa.

\section{Status Pekerjaan}

Variabel status pekerjaan didapatkan nilai $\mathrm{P}$ value 0,502 , artinya tidak ada hubungan antara status pekerjaan dengan kejadian skizofrenia pasien rawat inap di Rumah Sakit Jiwa Grhasia DIY. Nilai RP 1,068 dengan CI 95\% 0,890-1,281 (mencakup angka 1), artinya orang yang tidak bekerja bukan merupakan faktor risiko terjadinya skizofrenia (Sastroasmoro, 2011). Penelitian sejalan dengan penelitian Junaidi (2008) menunjukkan bahwa tidak ada hubungan antara status bekerja dengan kejadian gangguan jiwa.

Berbeda dengan hasil penelitian yang dilakukan Erlina dkk (2010) yang menunjukkan ada perbedaan yang bermakna antara skizofrenia dan non skizofrenia berdasar adanya status ekonomi $(\mathrm{OR}=6,00$ : 95\% CI: 2,52-14,60, $\mathrm{p}=0,000)$. Status ekonomi rendah mempunyai risiko 6,00 kali untuk mengalami gangguan jiwa skizofrenia dibandingkan status ekonomi tinggi. Hal ini didukung pendapat Jean dan Canto, (2005) yaitu ada beberapa faktor psikososial yang mempengaruhi gangguan jiwa skizofrenia, yaitu sosial ekonomi rendah dan stres lingkungan. Mallet et al (2002) menambhakan bahwa kehilangan orangtua dan pengangguran merupakan faktor psikososial yang dapat mempengaruhi terjadinya gangguan jiwa skizofrenia. Hasil penelitian Mallet et al (2002) yang menyatakan ada hubungan yang bermakna antara status pekerjaan dengan timbulnya skizofrenia $(\mathrm{OR}=5,5(95 \% \mathrm{CI}$ $2,59-11,68), p=0,000)$.

Status ekonomi rendah sangat mempengaruhi kehidupan seseorang. Beberaapa ahli tidak mempertimbangkan kemiskinan (status ekonomi rendah) sebagai faktor risiko, tetapi faktor yang menyertai bertanggungjawab atas timbulnya gangguan kesehatan. Menurut Graham (1989), keluarga adalah faktor perantara yang paling penting. Ketika kehidupan keluarga dipengaruhi oleh penyebab lingkungan (rumah yang kecil, tidak adanya waktu dan rasa aman) maka hal ini merupakan beban bagi orangtua yang akibatnya akan mempengaruhi kesehatan anak. Kemiskinan ditandai dengan sedikitnya dukungan, keselamatan, tidak adanya ruang sehingga terlalu sesak, tidak adanya kebebasan pribadi, ketidakpastian dalam masalah ekonomi yang akhirnya mungkin menimbulkan risiko kesehatan bagi keluarga (Erlina dkk, 2010).

Menurut Van Den (1991) orang yang tidak bekerja akan lebih mudah menjadi stres yang berhubungan dengaan tingginya kadar hormon stres (kadar cathecholamine) dan mengakibatkan ketidakberdayaan. Kessler et al, (2005) menambahkan, orang yang bekerja memiliki rasa optimis terhadap masa 
depaan dan lebih memiliki semangat hidup yang lebih besar dibandingkan dengaan yang tidak bekerja. Menurut Smet (1993) setiap kerja mempunyai stress agents yang potensial, tetapi masing-masing bervariasi dalam tingkatan pengalaman stresnya. Yang biasanya terjadi adalam kombinasi dari faktor stres yang kemudian menjadi tidak sehat (Erlina dkk, 2010).

Terjadinya skizofrenia pada orang yang tidak bekerja bukan hanya dipengaruhi oleh faktor itu saja. Akan tetapi dapat pula dipengaruhi oleh faktor lain seperti adanya faktor keturunan, adanya stresor psikososial masalah hubungan interpersonal maupun faktor keluarga yang mendukung terjadinya stres seseorang yang berstatus tidak bekerja. Hal ini sejalan dengan teori Gordon (1950) dalam Rajab (2008) bahwa lingkungan sosial sangat berpengaruh terhadap kesehatan mental atau jiwa seseorang. Interaksi ini akan terus berjalan dan saling mempengaruhi seperti roda yang berputar.

\section{Simpulan}

Berdasarkan hasil penelitian ini menunjukkan bahwa faktor risiko kejadian skizofrenia di Rumah Sakit Jiwa Grhasia DIY adalah faktor keturunan dan stresor psikososial dari masalah hubungan interpersonal dan faktor keluarga. Diharapkan kepada Rumah Sakit Jiwa Grhasia DIY, meningkatkan promosi kesehatan berupa promosi kesehatan mental, psiko edukatif baik untuk penderita skizofrenia, keluarga maupun masyarakat. Hal ini untuk menambah pengetahuan dan dapat meminimalisir kekambuhan serta stigma negatif masyarakat kepada penderita skizofrenia.

\section{Daftar Pustaka}

Akal, Burcin. N., and Dogan, Orhan. (2010). Potential Risk Factor for Schizophrenia in Sivas Turkey. Research Article. Archives of Neuropsychiatry. Vol. 47, Hal 230-236.

Amirudin. (2010). Analisis Faktor yang Berhubungan dengan Kejadian Gangguan Jiwa Skizofrenia di Rumah Sakit Jiwa Provinsi Sulawesi Tenggara Tahun 2010. Tesis. Program Pascasarjana Universitas Hasanuddin: Makasar.

Arif, I. S. (2006). Skizofrenia Memahami Dinamika Keluarga Pasien. Bandung: Refika Aditama.

Brown AS, Schaefer CA, Wyatt RJ et al. (2002). Paternal age and risk of schizophrenia in adult offspring. Am J Psychiatry. 159:1528-33.

Byrne M, Agerbo E, Ewald H et al. (2003). Parental age and risk of schizophrenia: a case-control study. Arch Gen Psychiatry. 60:673-8.

Departemen Kesehatan Republik Indonesia. (2015). Schizophrenia. Diunduh dari http://bbtklppjakarta.pppl.depkes. go.id/assets/files/downloads/f1375258333schizophrenia.pdf.

El-Saadi, O., Pedersen CB, McNeil TF et al. (2004). Paternal and Maternal Age as Risk Factors for Psychosis: Findings from Denmark, Sweden and Australia. Schizophr Res. 67:227-36.

Erlina, Soewadi, dan Pramono, D. 2010, Faktor-faktor yang Berperan terhadap Timbulnya Skizofrenia pada Pasien Rawat Jalan di Rumah Sakit Jiwa Prof. HB Saanin Padang Sumatera Barat. Berita Kedokteran Masyarakat, 
Vol. 26, No. 2, Hal: 71-80.

Fakhari, A., Ranjbar, F., Dadashzadeh, H., Moghaddas F. (2005). An Epidemiological Survey of Mental Disosders Among Adult In The North, West Area of Tabriz, Iran. Departement of Psychiatry, Iran.

Gunarsa, S. D. (2004). Bunga Rampai Psikologi Perkembangan: dari Anak Sampai Usia Lanjut. Jakarta: BPK Gunung Mulia.

Hawari, D. (2001). Pendekatan Holistik pada Gangguan Jiwa Skizofrenia. Jakarta: Badan Penerbit Fakultas Kedokteran Universitas Indonesia.

Hawari. (2014). Skizofrenia Pendekatan Holistik (BPSS) Bio-Psiko-SosialSpiritual Edisi Ketiga. Jakarta: Badan Penerbit Fakultas Kedokteran Universitas Indonesia.

Jean, PS., dan Canto, E. (2005). Social Defeat: Risk Factor Of Schizophrenia. British Journal Of Psychiatry. 187:101-102

Junaidi. (2008). Faktor-faktor Psikososial yang Berpengaruh Terhadap Gangguan Jiwa di Kecamatan Ingin Jaya Kabupaten Aceh Besar. Karya Ilmiah Paripurna. Yogyakarta: Fakultas Kedokteran Universitas Gajah Mada.

Kumpulan Artikel Kesehatan. 2016. FaktorFaktor yang Mempengaruhi: http:// www.ruanginfoguru.com/2014/06/faktorfaktor-yang-mempengaruhi.html. Akses 16 April 2016: Yogyakarta.

Mallet, R., Leff, J., Bhugra, D., Pang, D., Zhao Jing, H. (2002). Social Environment, Ethnicity and Schizophrenia. Social Psychiatry
Section. Institute Of Psychiatry. De Crespigny Park. London, SES 8AF, UK.

McGrath JJ, Susser ES. (2009). New Directions in the Epidemiology of Schizophrenia. Med J Aust. 190 (suppl 4): s.7-9.

McGrath JJ, Welham JL. (1999). Season of Birth and Schizophrenia: a Systematic Review and Meta-analysis of Data from Southern Hemisphere. Schizophr Res. 35:237-42.

Notoatmodjo, S. (2007). Promosi Kesehatan dan Ilmu Perilaku. Jakarta: Rineka Cipta.

Puspitasari, E. P. (2009). Peran Dukungan Keluarga pada Penanganan Penderita Skizofrenia. Skripsi. Fakultas Psikologi Universitas Muhammadiyah Surakarta.

Rajab, W. (2008). Buku Ajar Epidemiologi untuk Mahasiswa Kebidanan. Jakarta: EGC.

Read, J., Van, O.J., Morrison, AP., Ross, CA. (2005). Childhood Trauma, Psychosis And Schizophrenia: a Literature Review with Theoretical and Clinical Implications. Acta Psychiatry Scandanavica. 112:330-50

Riset Kesehatan Dasar. (2007). Badan Penelitian dan Pengembangan Kesehatan Republik Indonesia. Jakarta.

Riset Kesehatan Dasar. (2013). Badan Penelitian dan Pengembangan Kesehatan Republik Indonesia. Jakarta.

Sastroasmoro, S. (2011). Dasar-dasar Metodologi Penelitian Klinis Edisi 
ke-4. Jakarta: Sagung Seto.

Setiyowati, Y. (2012). Hubungan Faktor Riwayat Keluarga dan Stresor Psikososial dengan Kejadian Skizofrenia di Kabupaten Kebumen. Tesis. Yogyakarta: Fakultas Kedokteran Universitas Gajah Mada.

SIMRS Jiwa Grhasia Tahun 2015. (2015). Laporan Data 10 Besar Penyakit Rawat Inap Rumah Sakit Jiwa Grhasia Bulan Januari - Juni 2015. Yogyakarta: Rumah Sakit Jiwa Grhasia.

Sue, D., Sue, D. W., Sue, D., Sue, S. (2014). Essentials of Understanding Abnormal Behavior Second Edition, Wadsworth, USA: Cengage Learning.

Tandon R, Keshavan MS, Nasrallah HA. (2008). Schizophrenia, "Just The Facts" What We Know In 2008. Epidemiology And Etiology. Schizophr Res. 102:1-18
Tien AY, Eaton WW. (1992). Psychopathologic precursors and sociodemographic risk factors for the schizophrenia syndrome. Arch Gen Psychiatry. 49:37-46.

Townsead, D., Lisa., D. A., Cristina, Y. D., Findling, L. R. (2007). Family Conflict Moderates Respone to Pharmachology Intervensi in Pediatric Bipolar Disorder. Journal of Child and Adolescent Psychopharmachology. vol. 17 , no. 6 , Hal: 843-852.

Wahlbeck K, Forsen T, Osmond C et al. (2001). Association of Schizophrenia with Low Maternal Body Mass Index, Small Size and Thinness During Childhood. Arch Gen Psychiatry. 58:48-52. 